\title{
Ehre hier ist Schande dort: \\ Hermann Sudermann and the Protean Concept of Honour
}

\author{
Alan Corkhill
}

This paper is not intended to fuel the debate on the compositional inadequacies of Sudermann's oeuvre. It is a well-established fact that his works were subjected to a barrage of negative criticism throughout his literary career. Subsequent literary historians either chose to ignore his writings or, like Albert Soergel, to continue the policy of denigration instigated from the very outset by staunch adversaries such as Maximilian Harden and Alfred Kerr. ${ }^{1}$ The following investigation seeks to locate, define and evaluate the ubiquitous references to honour within a cross-section of early drama and prose. Obviously Sudermann's four-act social comedy Die Ehre (1889) is central to the discussion. It is perhaps the most frequently and thoroughly analysed of the Sudermann plays, not merely from the perspective of the Ehrproblematik, but because of its social topicality and its Naturalistic properties. The works under scrutiny reveal a wide spectrum of modes of honour such as biblical, personal, family, collective and national honour. W. F. Mainland points to the "[. . . ] almost obsessional preoccupation with certain themes, notably honour, fidelity, the wanderer's return, and sex", ${ }^{2}$ but fails to account for this bias. In his confessional writings, notably Briefe Hermann Sudermanns an seine Frau and Das Bilderbuch meiner Jugend (1922) the author refrains from committing himself to a definition of what honour means to him both in a private and more universal sense. On the other hand, his pronouncements regarding its surrogate concept $P$ flicht were considerably less sporadic. Irmgard Leux's intensive study of Sudermann's personality drawn from autobiographical material in the Nachla B pinpoints as a recurring psychological conflict the dilemma of reconciling the amoral impulses of a Kraftnatur with the ethical responsibilities of a Pflichtmensch. ${ }^{3} \mathrm{~A}$ French critic Henri Schoen perceived the nexus between duty and honour in the following, albeit generalised terms: "Sudermann a une très haute idée du devoir, qu'il met bien au-dessus de l'honneur. Selon lui, chaque individu a son idéal, sa voie à suivre, et il doit être fidèle à cette voie qui lui est tracée". 4

In Sudermann's 'Entwicklungsroman' Frau Sorge (1887) the arbitrariness and relativity of the Ehrbegriff underlies the young hero's trauma in relating to himself and others. This regional novel set in Lithuania traces the mixed fortunes of Paul 
Meyröcker, the son of a small-time farmer who has mismanaged his financial affairs, thereby threatening to bring ruin and dishonour upon the whole family. Meyröcker proceeds to assume full responsibility for maintaining the viability of the enterprise and for shielding his mother from the taunts and insults of her choleric ne'er-do-well spouse. Though handicapped by a significant inferiority complex of Sudermannian proportions, Meyröcker is nevertheless intent on upward social mobility, as evidenced by his attraction to the daughter of a more prosperous neighbouring landowner. An autobiographical parallel suggests itself here, namely Sudermann's self-consciousness with regard to what he himself describes as the Kleinbürgermisere from which he hailed. 5

Meyröcker's oedipal relationship has some bearing on his attitude to honour, for he appends a Freudian qualifier to the biblical Fifth Commandment: "Du sollst Vater und Mutter ehren. - Den Vater um der Mutter willen". 6 When it comes to upholding the good name of the family the hero's sense of duty based on a conventional view of honour is seen to be increasingly at variance with social reality. His Ehrgefühl - as he repeatedly calls it - is put to the test in the defence of his two younger sisters whose virtue has been compromised through their liaison with the sons of the local squire. Meyröcker's obsessive insistence on a marriage deal to remove the blot of dishonour is initially ridiculed by the brothers, especially in view of the pecuniary infeasibility of such an arrangement. An appeal to their sense of honour over and above pragmatic considerations likewise proves ineffectual as Meyröcker's antiquated Ehrenkodex, nurtured by a pietistic upbringing, strikes no empathetic chord in the seducers:

Er [Meyröcker] faltete die Hände - seine Zähne klapperten, - und wie entgeistert starrte er sie an. - 'Ist es denn möglich? Ihr wollt nicht? Wollt wirklich nicht?

- Faßt ihr denn gar nicht, daß es eure Pflicht und Schuldigkeit ist, gutzumachen, was ihr gesündigt habt [. . . ] Sagt euch euer Ehrgefühl nicht, daß ihr andre nicht ehrlos machen dürtt? [. . . L Läßt euch euer Gewissen denn schlafen?'

'Höre auf', sagte Ulrich, dem ein Gefühl des Unbehagens fröstelnd über den Nacken lief. 7 ,

Finally reduced to issuing a death threat as a means of securing their unconditional assent, Meyröcker comes to the realisation that the 'new morality', a form of social Darwinism with Nietzschean undercurrents, no longer accommodates the chivalric notion of honour:

Baust du auf Recht und Ehrgefühl und willst im guten alles zum Guten wenden, so nennt man dich feige, und du wirst behandelt wie ein Hund. - Behandelst du aber 
die andern wie Hunde, gleich von vornherein, ohne zu bedenken, ob du im Recht bist oder nicht, so nennt man dich mutig, und alles gelingt dir, und du wirst ein Held. 8

But this outburst of self-assertiveness rapidly yields to a more familiar pattern of self-effacement: "So schmutzig erschien er sich, als ob nichts auf Erden ihn wieder rein waschen könnte". 9

Although the violation of Frauenehre is a central concern in the novel, Meyröcker's retaliatory impulses hardly resemble those of the piqued nobleman in a Castilian honour tragedy, since the former initially promised the offending parties 'Christian forgiveness' in exchange for the restitution of his sisters' 'lost honour', whereas the latter is invariably bound by the ritual of blood vengeance.

In the longer term Meyröcker's persistent attempts to remain true to his principles, i.e., to an instinctive sense of right and wrong (subjective honour), culminate in the breaking of Dame Care's figurative spell, of which wedlock to his childhood sweetheart and an elevation in social standing constitute the felicitous outcome. This is not to say that the hero is whitewashed as a paragon of virtue. After all, there is something pathologically unsavoury about his self-appointed role as guardian angel and purveyor of public morals. From a Freudian viewpoint such zealous protectiveness towards his siblings, which demands a fair deal of bravado, represents an overcompensation for a lack of self-esteem and for feelings of sexual inadequacy. Furthermore, the narrator makes it clear that at times vanity, expediency and pride masquerade under the banner of so-called honourable motives.

Sudermann's subsequent novel Der Katzensteg was published in 1889. As recently as 1975 it was reprinted, and a film adaptation appeared in the same year, although considerable liberties were taken with the original story-line. The novel is set during the Napoleonic Wars and focuses on the dire consequences of a young aristocrat's return to his ancestral estate in Poland following Bonaparte's exile. Despite having fought courageously for king and country, Baron Boleslav von Schranden is forced to bear the ignominy of his father's act of treachery in permitting a French unit to cross a footpath (Katzensteg) in order to launch a surprise rear-guard attack on a Prussian contingent. Although motivated by a genuine desire to rid the Polish people of their Prussian oppressors he had nonetheless been lynched to death by an angry mob of tenants and denied a Christian burial. The novel chronicles the frustrated efforts of young Boleslav to counter the slur on his good name, a task made all the harder by the rumour that he had retained the domestic services of his father's alleged mistress, Regine, the 
daughter of a village drunkard. Thus Boleslav has to combat the accusation of 'dishonour' on several fronts. He feels duty-bound to preserve family honour, obey the dictates of his own conscience (personal honour), continue to maintain the principles of military and national honour, while at the same time exposing the collective outrage of the villagers as weakness and hypocrisy. The daunting legacy of his father's actions is likened from the outset to the inexorable fatum weighing on the tragic hero of an antique drama. As in Frau Sorge the curse of the 'sins of the fathers' is singled out as a force to be reckoned with:

Was von 'Sünden der Väter' mitten darein klang, empfand er als Schimpf, ihm selber angetan, einen Schimpf, den er stillschweigend hinnehmen mußte, weil gegen die Schmach, die der Vater ihm als Erbe auf die Schultern geladen hatte, ein Auflehnen nicht möglich war. ${ }^{10}$

In the public arena Boleslav finds himself a victim of the rabble-rousing ploys of his arch-enemy Felix Merckel who, in a relentless endeavour to whip up patriotic, fervour, makes little more than a convenience of the word 'honour' on numerous occasions, thereby virtually stripping it of all meaning. The excesses of Hurrapatriotismus are only too patent in the following piece of rhetoric delivered by Merckel to his receptive kinsfolk:

Unser geliebtes Vaterland hat sich aus dem Staube zu neuem, ungeahntem Glanze wieder erhoben. Die meisten von uns haben auf dem Felde der Ehre geblutet oder doch ihre Brust den feindlichen Kugeln dargeboten. Wer ein guter Patriot ist, der trinke mit mir auf Preußens Ehre! ${ }^{11}$

For Boleslav, of course, honour signifies something much more pervasive than national pride or the less exalted pretensions of a kleinbürgerlicher Ehrbegriff. Aristocratic rank demands not merely respect for military fame, "die Ehre seiner soldatischen Vergangenheit"12, but also universal acknowledgement of the hereditary title of Ehrenmann ${ }^{13}$ with its attendant privileges and obligations. Thus the sullying of his father's reputation has far-reaching psychological and legal repercussions: "Ihr habt [. . . ] ihn und sein Geschlecht geächtet, verfemt, ehrlos und rechtlos gemacht". ${ }^{14}$

For all that, a sudden change of fortune coinciding with the surprise conferral of an Iron Cross for past distinctions together with a hand-written directive from the King himself to head the district Landwehr in an offensive against the regrouped Napoleonic armies, help to lessen the stigma of opprobrium. Ironically though, it is at this favourable turning point that the value of 'worldly honour' is undermined by the 
village pastor who, in a mood of self-righteous indignation, insists that Boleslav should 'honour' divine will by dismissing his servant-girl as an act of good faith. To make matters worse, Merckel, at the risk of insubordination, threatens to defy the military orders of his bitter opponent, choosing instead to champion a nebulous concept of honour that really only amounts to wounded pride and self-respect:

Meine Ehre geb ich um keinen Judaslohn preis! Meine Ehre läßt sich nicht zum Schweigen bringen! Meine Ehre verlangt, daß ich dem verfluchten Hund das Herz aus dem Leibe reiße! Und ich tu's. Diese Schande für unser Vaterland muß endlich einmal getilgt werden. Diese Pestbeule des preußischen Offizierskorps muß ausgeschnitten und ausgebrannt werden! Ich tu's! So wahr ich ein wackerer Soldat bin! So wahr ich für meine Ehre sterben will! ${ }^{15}$

Merckel's allusion to the Prussian Officer Corps is significant, especially if the historical scenario of the novel is interpreted as a thin disguise for the Wilhelminian age. By Sudermann's day all leftist thinkers and most liberal democrats deplored the arrogance and insolence of the Corps. Its peculiar code of honour allowed for a style of boorish behaviour repugnant to more cultivated circles.

As the novel nears its tragic climax with the slaying of Regine by her own father, it becomes clear that Merckel has not only succeeded in mobilising public sentiment against the von Schrandens on the spurious grounds of slighted national honour, but has also unscrupulously set a father at loggerheads with his own progeny by invoking an equally spurious notion of slighted family honour:

[. . .] und deine Ehre ist flöten gegangen und die Courage dazu [. . .] Du willst behaupten, daß du noch Ehre im Leib hast, und duldest, daß der Verführer frei mit ihr herumläuft und daß dein eigen Fleisch und Blut dich verachtet, deine Hand zurückschlägt - die undankbare, pflichtvergessene Person! ${ }^{16}$

By comparison, Odoardo Galotti in Lessing's bourgeois tragedy strikes the fatal blow out of deep love and compassion for Emilia and because - as George Fenwick Jones correctly deduces -,"death by honour [is] better than a life of shame, at least for a woman". ${ }^{17}$

Regine's violent end shocks Boleslav into the realisation that the von Schranden line is the sole cause of the inhumanity exhibited by the villagers. This epiphany, plus a strong feeling of accountability for the death of a maid who had honoured and obeyed him in the face of collective hostility, now prompt him to atone for the 'sins of the fathers' on the field of honour. In this climate of crumbling ethical values Boleslav abandons the myth of sacred duty in favour of a secular mode of reverentia: 
Es ist gut, daß in diesem Chaos, wo Gut und Böse, Recht und Unrecht, Ehre und Schmach wirr durcheinandertaumeln und wo selbst der alte Gott im Himmel ohnmächtig dahinschwindet, ein fester Pol uns übrigbleibt, um den sich alles aufs neue ordnen muß, ein Fels, an den wir Ertrinkenden uns klammern können und an dem zu scheitern selbst noch Wollust ist - das Vaterland! 18

This axiomatic statement contains the rudiments of Sudermann's own lifelong religious scepticism, a stance profoundly influenced by Feuerbach, Haeckel and Nietzsche. It would be erroneous, however, to conclude from Boleslav's mentality of dulce et decorum est pro patria mori that Sudermann wholeheartedly embraced the cult of patriotic honour, since in the first place he had rejected Hegel and outgrown his youthful enthusiasm for Bismarckian militarism. Furthermore, his upbringing in a partially Mennonite environment engendered an intrinsically pacifist outlook.

Turning now to the social satire Die Ehre, its première in Berlin's Lessing Theatre on the 27.11 .89 secured the fledgling playwright instant fame - unlike the ill-fated début production of Vor Sonnenaufgang, which a month before had unleashed a storm of protest and censure. In retrospect Sudermann must have been struck by the irony of this short-lived competitive edge, for in a letter to his spouse announcing Hauptmann's receipt of the 1912 Nobel Prize he draws on a punch-line from his just completed drama Der Bettler von Syrakus (1911) to contrast their professional fortunes: "Wohl möchte ich mit meinem Diokles zu ihm sprechen: "Warum Dir nichts als Ehren und mir nichts als Schmach?"'19

The pre-performance title Zweierlei Ehre was dropped by the theatrical director, although it was really far more apposite as a description of the double standards observed by the occupants of two quite distinct social milieus in their respective appraisal of honourable conduct. The stage action moves backwards and forwards between two apartments under the same roof. After a long absence in the East Indies Robert Heinecke returns to Berlin to visit his working-class parents only to view as a blemish on the family's honour the discovery that, with tacit parental consent, his cherished sister Alma has been blatantly entertaining intimate relations with the son of his own benefactor. Thoroughly outraged that Alma's social inferiority has been taken advantage of and her virtue compromised, Heinecke demands 'satisfaction', but learns to his dismay that the 'nouveau-riche' Kommerzienrat Mühlingk has guaranteed appropriate satisfaction in the form of a generous cash settlement accepted by his parents without reservation. The very same day on which payment is made, Heinecke is dismissed from the Mühlingks' employ and is summoned to hand over the ledgers. He 
hastens next door fully intending to shoot down his sister's seducer in cold blood, but is brought to his senses by Count Trast, a millionaire coffee magnate and confidant. In the ensuing showdown between Vorderhaus and Hinterhaus the Kommerzienrat's daughter Leonore stands by Heinecke and prepares to elope with him. The latter's rising fortunes are further enhanced by Trast's unpredicted elevation of his associate to the status of sole heir, whereupon the love-birds depart for happier climes.

The upstairs-downstairs scenario is by no means new to German literature. Some fifty years earlier Nestroy had witnessed the success of his theatrical farce Zu ebener Erde und erster Stock, and Sudermann's familiarity with its content could be safely assumed. Nor was the playwright able to lay claim to originality in the figure of Count Trast, the urbane raisonneur of the piece, since his wordy pronouncements on the relativity of honour are largely modelled on those of Prosper Courament in Sardou's salon drama Les Pattes de Mouche (1860). Trast's (in)famous diatribe occurs in Act. 2 , Scene 11, where, in diametrical opposition to the archaic and myopic notion of Kavaliersehre defended by an immature aristocratic reserve officer, he proceeds to explode some of the traditional myths surrounding honour:

Was wir gemeinhin Ehre nennen, das ist wohl nichts weiter als der Schatten, den wir werfen, wenn die Sonne der öffentlichen Achtung uns bescheint. - Aber das Schlimmste bei allem ist, daß wir so viel verschiedene Sorten von 'Ehre' besitzen als gesellschaftliche Kreise und Schichten. ${ }^{20}$

Noteworthy is the increasing topicality of a relativistic conception of Ehre in the political sphere. Fenwick Jones in a footnote to his brief evaluation of the play quotes from the 1896 speech of a prominent MP, during which the latter had called into question the aura of privilege associated with exalted military rank: "Ich kann nicht zugeben, daß der Offiziersstand eine besondere Ehre habe; [. . . ] die Ehre des Arbeiters, Handwerkers, Kautmanns, Juristen ist dieselbe wie die des Offiziers".21

Ironically Robert Heinecke is just as stubbornly uncompromising as the headstrong lieutenant with regard to breaches of honourable behaviour, despite Trast's sociologically pertinent illustrations of the inescapable truism that every caste has invented its eigene Ehre. ${ }^{22}$ Indeed, Heinecke seems to share with Paul Meyröcker an almost fetishistic overprotectiveness towards his 'fallen' sister: "Die Kinderseele, die er [Kurt Mühlingk] in den Schmutz getreten hat, kann er mir nicht wiedergeben". ${ }^{23}$ But leaving aside the psychological hang-ups conditioning Heinecke's Ehrbegriff, the strongest determinants are identified as being socio-economic, notably the persuasiveness of money: 
Jene [die Mühlingks] haben uns in Schande gebracht. Gut - Aber wir waren ohne Schuld. Wir brauchten uns vor niemandem zu schämen. - Man kann mir meine Ehre stehlen, wie man mir mein Portemonnaie stiehlt. - Dagegen ist man wehrlos.

- Aber wenn wir uns unser bißchen Ehre bezahlen lassen - mit barem Geld dann sind wir ehrlos gewesen von jeher. ${ }^{24}$

For her part, Leonore arrives at the same conclusion and is accordingly quick to condemn the parental practice of "[. . . ] immer bezahlen - Ehre, Recht, Liebe - alles bezahlen!"25 Such statements tend to reinforce the impression that the play is not primarily about honour per se, but is more concerned with exposing the infectious evils of entrepreneurial capitalism during the Gründerjahre. Bernd Witte argues along similar lines in his postscript to the 1982 Reclam reprint: "Nicht die im Titel genannte und die dramatische Handlung vorwärtstreibende Infragestellung überholter Ehrbegriffe steht nämlich im Mittelpunkt des Stückes, sondern die Problematik des gesellschaftlichen Aufsteigers". 26 Of course Die Ehre, in contrast to the more serious attempts of Naturalistic theatre to portray social injustice with photographical realism, is meant to be full of comic relief, so that, in point of fact, the difficulties confronting the parvenu are treated in a lighthearted fashion. After all, Heinecke is eventually - albeit idealistically - catapulted up the social ladder.

As far as the play's querying of überholte Ehrbegriffe is concerned, critics agree unanimously that Sudermann posits no tangible alternatives. Even the call of 'duty', which the coffee tycoon places on a higher pedestal than 'honour', is not elaborated. And what is actually meant by the neue Ehre ${ }^{27}$ that Heinecke feels obliged to adopt in the closing lines? At least in the maelstrom of transvalued values in which Boleslav von Schranden is immersed, it is possible to cling to the vision of national honour, whereas here Count Trast can nihilistically proclaim: "Es gibt gar keine Ehre!"28

Two further works which exemplify the motif of honour are the one-act plays Teja and Fritzchen from the trilogy Morituri (1896). Whilst in Die Ehre a fatal duel is narrowly averted, ${ }^{29}$ the titular protagonist of Fritzchen is no match for the proven duelling skills of his antagonist, a senior regimental officer whom he has publicly and privately offended as a direct consequence of a sordid affair with the latter's wife. The tightly-knit plot spans the brief interlude required by Fritzchen to break the news of this scandal and his impending demise to his next of kin. His destiny is sealed by the announcement that an Ehrenrat has upheld the challenge and sanctioned the duel. Both father and son are 'outwardly' relieved at this verdict, as it salvages the reputation of a distinguished military household. Fritzchen departs to the final rendezvous without 
initiating his mother into his sinister intentions.

Perhaps the message of this playlet had already been adumbrated by Trast in his ridiculing of any sacrifice of life resulting from blind obedience to an anachronistic Ehrenkodex. ${ }^{30}$ It is interesting to note that by the 1890 s duelling had become a highly contentious social and political issue; all the more so when in 1896 public opinion was greatly aroused by a tragic duel fought by two officers of the reserve, despite a ruling under the prevailing military code that duelling was to be condoned only as a last resort. Imperial intervention the following year led to an enforcement of the authority vested in the military Ehrenrat. At the same time the accepted practice of expulsion from army sevice continued for officers unwilling to respond to a challenge. In Fritzchen no such option is even hinted at. On the literary scene the controversy over duelling found its most poignant expression in Fontane's novels. Cécile (1886) and Effi Briest (1895). Significant in this respect is Wüllersdorf's influential remark concerning the tyranny of a rigid martial code, "[. . . ] unser Ehrenkultus ist ein Götzendienst, aber wir müssen uns ihm unterwerfen, solange der Götze gilt". 31

In the first playlet of the cycle, Teja, the besieged Ostrogoths of $553 \mathrm{~B}$. C. are the 'morituri' as they prepare for battle and certain death on the slopes of Vesuvius. The warrior king exhorts his troops to fight stoically in defence of national gloire and to achieve an inner moral victory in the face of overwhelming physical odds. Thus according to Henri Schoen, "au lieu de victimes passives condamnées à la mort, nous avons des héros actifs qui vont au-devant d'elle et font volontairement le sacrifice de leur vie pour sauver leur honneur". 32

The final work to be considered here is the political drama Es lebe das Leben (1902), since it explores, among other things, further anomalies in the duelling ritual. Located in the Berlin of the 1890 s against the backdrop of an election campaign, the play contains realistic insights into the world of political intrigue which Sudermann may well have derived from his own experience as a parliamentary journalist on the Deutsches Reichsblatt. A tragic conflict is set in motion by the threat of a scandal involving the private lives of two Junker MPs. The subject of honour is raised. Count Michael von Kellinghausen is confronted with a double dilemma. On the one hand, his only redress is to sue the instigator of the libel, a socialist opponent, in a court of law; since such disputes were no longer settled by 'affairs of honour'. By the same token, a duel with his close friend Baron Richard von Völkerlingk who has caused the scandal through his extramarital liaison with his wife, is promptly ruled out.

The whole issue of outmoded tenets of honour is tackled by von Völkerlingk's son, a 
progressive thinker in touch with the new spirit of liberalism and the advocate of an internalisation of honour. It should by possible, he argues at a crucial juncture in the action, for each individual to invoke an inner Richter ${ }^{33}$ as a yardstick for determining the extent of personal guilt and the appropriate punitive measures; and like Count Trast he is inclined to view external codes of honour sociologically. Thus the encrusted laws of the Junker ruling class are interpretable as a defence mechanism against the competing interests of a rising bourgeoisie and proletariat. ${ }^{34}$

A tragic twist to the plot occurs when Beate von Kellinghausen, the unfaithful though highly principled spouse, takes the above-mentioned theory of self-accountability to its extreme and commits suicide under circumstances not unlike those prompting Anna Karenin's or Hedda Gabler's acts of self-sacrifice.

To sum up then - it has been shown that by juxtaposing and contrasting a range of attitudes towards honour, Sudermann effectively revealed (without recourse to authorial commentary) the contradictions and ambiguities inherent within what his age termed the Ehrenkodex. Attuned to the Zeitgeist he recorded the clash between reactionary and evolutionary notions of honour, in particular the collision of aristocratic pretensions with the more materialistically oriented viewpoint of the nouveau-riche. As Harald Weinrich rightly concludes in his article on the mythology of honour, commercial and industrial circles began automatically to equate the idea of 'intact honour' with solvency, likewise 'dishonour' with bankruptcy. ${ }^{35}$ In the second place, Sudermann captures something of the mood of burgeoning nationalism and its cognate association with imperialistic honour as a 19 th century pan-European phenomenon.

But quite apart from documenting the sociological dimensions of honour, Sudermann's fiction externalises the psychological and moral conflict arising from the quandary of accommodation to conventional or self-imposed criteria of honourable behaviour. That the author himself possessed a low threshold of self-esteem clearly emerges from a passage in Bilderbuch meiner Jugend where he speaks unequivocally of the "Bewußtsein meines Unwertes, das tief in mir festsaß". ${ }^{36}$ This admission helps to clarify the important question left unchallenged by W. F. Mainland, namely why Sudermann should have lent such prominence to the motif of honour. Certainly the fashionableness of its theme and variations - especially the outcry over duelling - is a plausible justification in itself. But from a purely personal angle, thorough treatment of the Ehrbegriff may well have been tantamount to a desire to contextualise artistically recurring phobias centering on self-worth. There can be little doubt that 
adverse publicity from the same implacable lobby of critics was bound to result in a loss both of face and faith. Indeed, in a diary entry of 17. 5.1916 Sudermann complained bitterly of "Entehrung durch jene Verleumderbande". 37

Judging from a broader literary historical perspective, it can be safely claimed that Sudermann had as many essential things to say about honour as his contemporaries Ibsen, Fontane, Schnitzler and Shaw. Trast's throw-away lines have their direct equivalent in the scores of Shavian witticisms pertaining to honour and duty. Furthermore, Sudermann's approach to honour was demonstrably as seriously minded as Fontane's, as satirical as Schnitzler's and as sceptical as Shaw's.

\section{Footnotes}

1 Albert Soergel, Dichtung und Dichter der Zeit. Eine Schilderung der deutschen Literatur der letzten Jahrzehnte, Leipzig 1911. See also the article by Klaus Matthias, "Kerr und die Folgen - Analyse der Sudermann-Kritik als Perspektive einer Neubewertung seiner Dramen" in Hermann Sudermann, Werk und Wirkung, ed. Walter T. Rix, Würzburg 1980, pp. 31-69.

2 William M. Mainland, "Hermann Sudermann", German Men of Letters, Vol.II, ed. Alex Natan, London 1963, p. 43.

3 Irmgard Leux, "Hermann Sudermann (1857-1928). Eine individualanalytische und schaffenspsychologische Studie", Journal für Psychologie und Neurologie 42. (1931), p.126.

4 Henri Schoen, Hermann Sudermann, Paris 1904, p. 58.

5 Briefe Hermann Sudermanns an seine Frau (1891-1924), ed. Irmgard Leux, Stuttgart 1932, p. 311 (letter of 13. 5. 1920) Cf. the statement: "Daß mein Elternhaus sich nicht zu den ersten - den Honoratioren - zählen wollte und durfte, sondern im Mittelstand seinen Platz hatte, war der große Schmerz meiner Kindheit", Hermann Sudermann, Das Bilderbuch meiner Jugend, Berlin 1922, p. 56.

6 Hermann Sudermann, Frau Sorge, Würzburg 1951, p. 97. Text citations come from the reprinted edition.

7 Ibid., p. 219.

8 Ibid., p. 230.

9 Ibid. 
10 Hermann Sudermann, Der Katzensteg, Stuttgart 1957, p. 20. Text citations come from the reprinted edition.

11 Ibid., p. 60.

12 Ibid., p. 162.

13 lbid., p. 178.

14 lbid., p. 179.

15 Ibid., p. 223.

16 lbid., p. 242.

17 George Fenwick Jones, Honor in German Literature, Chapel Hill 1959, p. 162.

18 Katzensteg, pp. 265-6.

19 Briefe, p. 270 (15.11.1912).

20 Hermann Sudermann, Die Ehre, Stuttgart 1982, pp. 52-53. Text citations come from the reprinted facsimile editicn. Nachwort by Bernd Witte.

21 Fenwick Jones cites F. von Lipperheide, Sprichwörterbuch Berlin 1907, p. 134.

22 Ehre, p. 32.

23 Ibid., p. 63.

24 lbid., p. 78.

25 Ibid., p. 90.

26 Ehre, pp. 118-119.

27 lbid., p. 105.

28 lbid., p. 52.

29 In the original five-act manuscript Die Ehre des Hinterhauses a duel is also averted in the nick of time. See Bernd Witte's careful study of the "Nachlaß" material (Ehre, p. 129ff).

30 Ehre, p. 55. Cf. Schopenhauer's sceptical observation "[. . .] daß schon öfter Leute, denen die Wiederherstellung ihrer verwundeten ritterlichen Ehre [. . .] unmöglich war, aus Verzweiflung darüber sich selbst das Leben genommen und so ein tragikomisches Ende gefunden haben", Arthur Schopenhauers sämtliche Werke, ed. P. Deussen, Munich 1913. Aphorismen zur Lebensweisheit, Vol. IV, pp. 427-428. 
31 Theodor Fontane, Effi Briest, Frankfurt/M. 1967, p.185.

32 Schoen, p. 218.

33 Hermann Sudermann, Es lebe das Leben. Drama in fünf Akten, Stuttgart \& Berlin 1902 , p. 79.

34 Ibid., p. 80.

35 Harald Weinrich, "Mythologie der. Ehre", Terror und Spiel. Probleme der Mythenrezeption, ed. Manfred Fuhrmann, Munich 1971, p. 345.

36 Bilderbuch, p. 96. Cf. on the subject of Sudermann's complexes: Paul K. Whitaker, "The Inferiority Complex in Hermann Sudermann's Life and Works", MDU 40 (1948), pp. 69-81.

37 Cited from Dorothea Kuhn, "Zum Nachlaß von Hermann Sudermann", Jahrbuch der deutschen Schiller-Gesellschaft XXIV (1980), p. 468. 